\title{
PERAN ORANG TUA DALAM MENGEMBANGKAN PERILAKU BERBAGI DAN MENOLONG PADA ANAK USIA DINI
}

\author{
Fitria Khairunnisa $^{1}$, Fidesrinur $^{1}$ \\ ${ }^{1}$ Program Studi Pendidikan Guru Pendidikan Anak Usia Dini, Fakultas Psikologi dan Pendidikan, Universitas \\ Al Azhar Indonesia, Jl. Sisingamangaraja, Jakarta Selatan, 12110
}

Penulis untuk korespondensi/ E-mail: fitria02khairunnisa@gmail.com

\begin{abstract}
Abstrak - Penelitian ini bertujuan untuk mendeskripsikan peran orang tua dalam mengembangkan perilaku berbagi dan menolong pada anak serta mendeskripsikan hambatan yang didapatkan orang tua dalam mengembangkan perilaku berbagi dan menolong pada anak. Penelitian dilakukan menggunakan metode penelitian deskriptif. Subjek penelitian berjumlah 3 orang keluarga. Pengumpulan data menggunakan observasi dan wawancara terstruktur. Analisis data menggunakan model Milles and Hubberman dengan 4 tahapan.. Simpulan hasil penelitian ini adalah: 1). orang tua melaksanakan perannya sebagai pendidik dengan cara mencontohkan, mengajarkan menasehati anak agar memiliki perilaku berbagi, menggunakan metode bercerita dan bermain peran, serta melibatkan anak untuk melakukan pekerjaan di rumah; 2). Orang tua melakukan perannya sebagai pembimbing tetapi belum maksimal, karena tidak adanya kegiatan atau upaya orang tua yang menjadi acuan agar anak bisa berperilaku berbagi; 3). Orang tua melakukan perannya sebagai motivator kepada anak tetapi seringkali tujuannya hanya untuk menghilangkan sikap anak yang sedang marah atau emosinya tidak baik, dan 4). Orang tua melaksanakan perannya sebagai fasilitator dengan menyisihkan uang dan makanan untuk diberikan kepada orang lain, serta menggunakan video berisi cerita perilaku berbagai. Adapun kendala yang dialami adalah: 1). emosi dan mood anak yang mudah berubah; 2 ). konsistensi dalam pelaksanaan pengajaran antara lingkungan rumah dan lingkungan bermain serta konsistensi dalam menjalankan program atau kegiatan yang sudah dibuat untuk anak; dan, 3). Terkait motivasi, seringkali apa yang dibutuhkan dan diinginkan oleh anak tidak dapat dipenuhi orang karena faktor keuangan rumah tangga.
\end{abstract}

\section{Kata Kunci - Peran Orang Tua, Perilaku Berbagi dan Menolong, Anak Usia Dini.}

Abstract - This study aims to describe the role of parents in developing sharing and helping behavior in children and to describe the obstacles that parents face in developing sharing and helping behavior in children. The research was conducted using descriptive research methods. The research subjects were 3 families. Collecting data using observation and structured interviews. Data analysis used the Milles and Hubberman model with 4 stages. The conclusions of this research are: 1). parents carry out their role as educators by setting an example, teaching and advising children to have sharing behavior, using storytelling and role-playing methods, and involving children to do homework; 2). Parents carry out their role as mentors but are not optimal, because there are no parental activities or efforts that become references so that children can behave in sharing; 3). Parents perform their role as motivators to children but often the goal is only to eliminate the attitude of children who are angry or have bad emotions, and 4). Parents carry out their role as facilitators by setting aside money and food to give to others, as well as using videos containing stories of various behaviors. The obstacles experienced are: 1). the child's volatile emotions and moods; 2). consistency in the implementation of teaching between the home environment and the play environment as well as consistency in carrying out programs or activities that have been made for children; and, 3). Regarding motivation, often what people need and want cannot be fulfilled because of household finances.

Keywords - Participation of Parents, Helping and Giving Behavior, Early Childhood. 


\section{PENDAHULUAN}

U ndang-Undang Republik Indonesia Nomor 20 Tahun 2003 tentang Sistem Pendidikan Nasional khususnya dalam bab I pasal 1 butir 14 menyebutkan, anak usia dini adalah anak usia sejak lahir hingga usia enam tahun. Masa usia dini disebut juga dengan masa emas (golden age). Masa yang sangat tepat dalam menstimulasi seluruh aspek perkembangan anak, seperti bahasa, kognitif, sosial emosional, agama dan moral, motorik kasar dan halus, serta seni. Masa ini juga menjadi masa yang tepat untuk membentuk perilaku-perilaku baik dalam diri anak.

Secara umum, perilaku manusia dapat dikelompokkan ke dalam dunia jenis, yakni: perilaku positif dan perilaku negatif. Diantara perilaku positif adalah perilaku prososial. Baron \& Byrne (2005) menjelaskan perilaku prososial sebagai suatu tindakan menolong yang menguntungkan orang lain tanpa harus menyediakan suatu keuntungan langsung pada tindakan tersebut, dan mungkin bahkan melibatkan suatu resiko bagi orang yang menolongnya. Perilaku prososial adalah perilaku sukarela yang memiliki tujuan menguntungkan orang lain. Perilaku prososial meliputi segala bentuk tindakan yang dilakukan atau direncanakan untuk menolong orang lain tanpa memperdulikan motif-motif si penolong (Widyastuti, 2014: 107). Perilaku prososial adalah perilaku yang mencerminkan kepedulian atau perhatian dari seorang anak ke anak lainnya, misalnya dengan membantu, menghibur, atau hanya tersenyum pada anak lainnya. (Copeland, dkk. dalam Beaty, 2013: 169).

Perilaku prososial membuat seseorang dapat hidup secara bersama dengan produktif. Selain itu, perilaku prososial dapat memberikan dampak positif bagi kesehatan fisik, kognitif, dan psikologis (Lay \& Hoppmann, 2015). Lebih lanjut Wentzel (2015) menyatakan, perilaku prososial berupa perilaku berbagi, bekerjasama dan saling menolong. Perilaku prososial adalah segala bentuk tindakan yang dilakukan baik secara sukarela ataupun direncanakan yang bertujuan untuk menolong orang lain tanpa menginginkan timbal balik. Perilaku prososial membantu seorang untuk bergaul dalam masyarakat, bertemu dan berinteraksi dengan berbagai macam pribadi serta menjadikan kita manusia (Beaty, 2013: 168).

Terdapat bermacam-macam jenis perilaku prososial. Eisenberg dan Fabes (dalam Carlo \& Randall, 2002), mengidentifikasi 6 jenis perilaku prososial, yaitu perilaku prososial altruisme, compliant, emotional, public, anonymous, dan dire. Sementara di dalam Standar Tingkat Pencapaian Perkembangan Anak pada aspek perkembangan Sosial Emosional, komponen perlaku prososial anak khususnya usia 5-6 tahun mencakup: Bermain dengan teman sebaya; Mengetahui perasaan temannya dan merespon secara wajar; Berbagi dengan orang lain Menghargai hak/pendapat/karya orang lain; Menggunakan cara yang diterima secara sosial dalam menyelesaikan masalah (menggunakan fikiran untuk menyelesaikan masalah); Bersikap kooperatif dengan teman; Menunjukkan sikap toleran; Mengekspresikan emosi yang sesuai dengan kondisi yang ada (senang-sedih-antusias dsb); dan. Mengenal tata krama dan sopan santun sesuai dengan nilai sosial budaya setempat.

Seyogyanya seorang anak adalah bagian terkecil dari keluarga, kehidupan bertetangga, bermasyarakat dan bernegara, dalam rangka menjadi bagian dan menjalankan peran di kehidupan dengan baik maka seorang anak perlu ditanamkan perilaku prososial sejak dini. Perilaku prososial yang dilakukan di lingkungan bermainnya dapat memperlihatkan bagaimana anak berperilaku di lingkungan keluarga.

Perilaku sosial pada manusia tidak tumbuh dan berkembang dengan sendirinya. Melainkan melalui proses panjang sejak anak usia dini hingga dewasa. Bisa dikatakan, pembentukan perilaku prososial orang dewasa atau tua, sangat dipengaruhi dan ditentukan oleh proses pembentukan di masa anak usia dini, atau anak-anak. Demikian pentingnya pembentukan prilaku sosial anak, lembaga pendidikan maupun lembaga riset sudah lama memikirkan cara-cara pembentukan perilaku sosial anak.

Sebagai orang yang terdekat, orang tua sangat berpengaruh besar dalam pembentukan perilaku prososial anak. Boleh dikatakan, ada-tidaknya perilaku sosial pada anak sangat ditentukan oleh ada-tidaknya perilaku sosial pada orang tuanya. Oleh karena itu, orang tua harus memberi dan menjadi contoh konkrit bagi anak-anaknya dalam perilaku sosial. Pada anak-anak usia dini, memberi contoh konkrit terkadang jauh lebih besar pengaruhnya daripada sekadar dalam bentuk nasihat.

Untuk mendukung hal itu orang tua juga harus memenuhi fasilitas yang dibutuhkan anak, mengontrol dan memastikan anak tetap mempunyai perilaku prososial baik di dalam dan di luar rumah 
serta memberikan motivasi ketika anak tidak semangat dalam menjalankan perilaku prososial yang diajarkan oleh orang tua. Ini sejalan dengan yang dikatakan oleh Nur \& Ahmid (2015: 22-23) bahwa peran orang tua dalam pendidikan mencakup: 1. Orang tua sebagai pendidik, yaitu mengupayakan perkembangan seluruh potensi anak, baik potensi afektif, kognitif dan potensi psikomotor; 2. Orang tua sebagai pendorong(motivator), yaitu daya penggerak atau pendorong untuk melakukan sesuatu (menumbuhkan motivasi pada anak dalam berperilaku); 3. Orang tua sebagai fasilitator, yaitu tugas orang tua yang menyediakan berbagai fasilitas belajar seperti tempat belajar, meja, kursi, penerangan, buku, alat tulis, dan lain-lain; dan 4 . Orang tua sebagai Pembimbing, yaitu peran orang tua yang tidak hanya memberikan fasilitas di rumah maupun di luar rumah tetapi juga harus mengarahkan atau mengajarkan anak untuk berperilaku baik di dalam rumah maupun di luar rumah secara konsisten.

Dacholfany dan Hasanah (2018) juga menyampaikan peran orang tua sebagai pendidik, sebagai berikut: 1. Sebagai Teladan atau Pemberi Contoh, maksudnya orang tua merupakan contoh pertama dan utama bagi anak maka dari itu orang tua harus memberikan contoh yang baik kepada anak agar anak akan melakukan tingka laku yang bai pula; 2. Sebagai Pembimbing, maksudnya orang tua sebagai pendidik harus dapat membimbing serta membina anak-anak mereka dengan menanamkan perilaku baik sejak dini, agar anak terbiasa melakukan perilaku baik saat ia dewasa; 3 . Sebagai Fasilitator, maksudnya orang tua harus memfasilitasi sarana prasana agar anak bisa mengeksplor media dan menejelajah dunia lebih luas.

Selain itu, peranan lingkungan sosial yang baik pada anak akan berdampak positif sehingga anak memiliki penyesuaian diri yang baik. Perkembangan sosial dibutuhkan oleh anak usia dini untuk belajar mengetahui dan memahami lingkungan. Di dalam perkembangan sosial, anak dituntut untuk memiliki kemampuan yang sesuai dengan tuntutan sosial di mana mereka berada. Anak yang memiliki keterampilan sosial yang baik terhadap keluarga, teman sebaya, dan orang lain akan menampakkan perilaku menolong yang dikenal dengan perilaku prososial. Pengembangan perilaku prososial adalah satu jenis dengan kompetensi sosial yang penting dimiliki oleh anak usia dini.
Di dalam kenyataannya perilaku sosial tidak selalu terjadi dan terwujud dalam setiap diri manusia, termasuk pada anak-anak usia dini. Sebaliknya yang sering terjadi atau terwujud adalah sikap asosial. Sikap asosial mengacu kepada kurangnya motivasi seseorang dalam terlibat atau melakukan interaksi dengan individu atau kelompok lain. Sikap asocial sendiri berbeda dengan sikap anti sosial dimana antisosial mengandung perilaku membenci orang lain terhadap orang lain maupun tatanan sosial pada umumnya.

Burt, Donnellan, Iacono \& McGue (2011: 634) sebagaimana dikutip Nur Anisa dan kawan-kawan berpendapat, perilaku antisosial adalah sebagai perilaku-perilaku yang menyimpang dari normanorma, baik aturan keluarga, sekolah, masyarakat, maupun hukum. Perilaku antisosial dibedakan menjadi dua jenis, yaitu perilaku antisosial tampak (overt) dan tak tampak (covert). Perilaku antisosial yang tampak (overt) berupa perilaku agresif dan perilaku antisosial yang tak tampak (covert) berupa perilaku non-agresif serta perilaku melanggar peraturan dengan berbohong.

Supratiknya (2012: 86) sebagaimana dikutip Nur Anisa dan kawan-kawan mengungkapkan bahwa ciri-ciri perilaku antisosial pada masa kanak-kanak (usia 4-6 tahun) adalah sebagai berikut: sulit diatur, suka berkelahi, menunjukkan sikap bermusuhan, tidak patuh, agresif baik secara verbal maupun behavioral, senang membalas dendam, senang merusak (vandalisme), suka berdusta, mencuri, tempertantrums atau mengamuk. Lier, Waner, \& Vitaro (dalam Mulyasa, 2012) juga berpendapat bahwa perilaku antisosial anak usia dini berupa perilaku agresif dan perilaku merusak (vandalisme).

Berdasarkan observasi yang dilakukan peneliti di lingkungan, Jl. Laksana Karang Tengah RT 002 RW 008, peneliti menemukan anak-anak memiliki perilaku prososial di tempat bermain yang cukup baik. Hal ini terlihat dari adanya perilaku prososial anak yang dapat berkembang sesuai dengan indikator perkembangan perilaku prososial (Beaty, 2013: 170) sebagai berikut: 1. Menunjukan kepedulian pada orang lain yang sedang mengalamai kesusahan dan mengetahui bagaimana perasaan anak lain selama konflik (berbagi rasa, empati); 2. Berbagi dan memberikan sesuatu pada orang lain (berbagi barang, kemurahan hati); 3. Mengambil giliran dan memenuhi permintaan orang lain dengan mudah (kerjasama); 4. Membantu orang lain mengerjakan tugas (kepedulian, menolong). 
Selain itu ada juga anak yang perilaku prososialnya belum berkembang. Hal tersebut berdasarkan wawancara dengan beberapa orang tua anak tentang seberapa sering anak memunculkan perilaku prososial (berbagi, menolong, kerjasama, jujur, berderma) di rumah. Didapati hasil sebagai berikut: dari 6 orang anak hanya ada 2 orang yang perilaku prososialnya sesuai harapan (melakukan kegiatan berbagi, menolongm kerjasama dan berderma), 1 orang yang mulai berkembang dan anak 3 anak yang perilaku prososialnya kurang.

Demikian pentingnya orang tua dalam menanamkan perilaku prososial anak, peneliti tertarik untuk melakukan penelitian dengan judul "Peran Orang Tua dalam Mengembangkan Perilaku Berbagi dan Menolong pada Anak Usia 5-6 tahun di Lingkungan Jl. Laksana Karang Tengah, Lebak Bulus, Cilandak, Jakarta Selatan".

\section{Perilaku Berbagi}

Berbagi menurut Kamus Besar Bahasa Indonesia (KBBI) berasal dari kata dasar bagi pecahan dari sesuatu yang utuh; penggal; pecah. Jika ditambahkan imbuhan ber- maka maknanya menjadi membagi sesuatu, memberikan sesuatu. Berbagi dalam bahasa Arab dimaknai sebagai sedekah, berasal dari kata "shadaqa" yang berarti "benar" atau "jujur".

Ketika kata shadaqa diberikan penambahan huruf ta marbuta di akhir katanya, maka menjadi kata shadaqatun yang. bermakna "sedekah" atau "sesuatu yang diberikan dengan maksud mengharapkan keridahan dari Allah". Di dalam Al Qur'an, dapat ditemukan bahwa kata sahdaqatun yang mempunyai sinonim dengan kata ihsan berarti "kedermawanan atau kemurahan hati". Hafidhuddin menjelaskan kata sedekah didefinisikan "benar". Jadi orang yang suka bersedekah adalah orang yang benar pengakuan imannya.

Secara umum sedekah/berbagi ini dapat didefinisikan sebagai suatu pemberian yang diberikan oleh seseorang kepada orang lain secara spontan dan sukarela tanpa dibatasi oleh waktu dan jumlah tertentu. Misalnya anak memberikan/berbagi bekal makanannya kepada teman yang tidak membawa bekal.

\section{Menolong}

Menolong dalam Kamus Besar Bahasa Indonesia berarti membantu untuk meringankan beban (penderitaan, kesukaran, dsb), membantu dalam melakukan sesuatu, yaitu dapat berupa bantuan tenaga, waktu, ataupun dana. Sedangkan dalam bahasa Arab (mengutip kamus al-munawwir), kata menolong disebut dengan istilah taawun yang berarti tolong menolong, gotong royong, bantu membantu sesama manusia. Sedangkan menurut istilah adalah suatu pekerjaan atau perbuatan yang didasari pada hati nurani dan semata-mata mencari ridho Allah SWT. Taawun bisa dilakukan dengan apa saja tanpa ada aturan persyaratan, semua bisa melakukannya, baik yang masih kecil, muda ataupun tua, dalam mengerjakan kebaikan dan kebajikan. Taawun juga dapat diartikan sebagai sikap kebersamaan dan rasa saling memiliki dan saling membutuhkan antara satu dengan yang lainnya, sehingga dapat mewujudkan suatu pergaulan yang harmonis dan rukun. Al-quran menyebutkan bahwa taawun merupakan hal yang esensial bagi setiap muslim.

Umat Islam diperintahkan untuk saling tolong menolong terhadap sesama dalam perbuatan yang terpuji. Seperti yang tercantum dalam surat al maidah ayat 2 yang artinya: "Dan tolong menolonglah kalian dalam kebaikan dan takwa dan janganlah kalian tolong menolong dalam perbuatan dosa dan permusuhan. Bertakwalah kepada Allah, sesungguhnya Allah amat berat siksaan-Nya“.

Menurut Dovidio \& Penner (dalam Evalina, 2001: 11), menolong (helping) adalah suatu tindakan yang bertujuan menghasilkan keuntungan terhadap pihak lain. Perilaku menolong juga diartikan sebagai suatu tindakan yang menguntungkan orang lain tanpa harus menguntungkan si penolong secara langsung, bahkan kadang menimbulkan resiko bagi si penolong (Baron, Byrne \& Brascombe dalam Sarlito, 2009: 123).

\section{METODE PENELITIAN}

Penelitian ini menggunakan metode kualitatif dalam pendekatan deskripstif. Pendekatan kualitatif ini menggunakan metode deskriptif yaitu berupa kata kata, gambar dan bukan angka-angka.hal itu disebabkan oleh adanya penerapan metode kualitatif. Melalui pendekatan kualitatif diharapkan permasalahan dan berbagai fenomena dalam penelitian ini dapat diungkapkan secara mendalam dan jelas tentang bagaimana peran orang tua dalam mengembangkan perilaku berbagi dan menolong pada anak usia 5-6 tahun.

Tempat atau lokasi penelitian dilaksanakan sekitar Jl. Laksana Karang Tengah RT 002 RW 008, Kelurahan Lebak Bulus, Kecamatan Cilandak, 
Jakarta Selatan. RT 002 memiliki 125 Keluarga dari setiap rumah, kemudian dari jumlah terseut terdapat keluarga yang memiliki anak berusia 5-6 tahun sebanyak 12 anak yang artinya dari sebanyak 125 keluarga terdapat 12 keluarga yang masing-masing memiliki anak usia 5-6 tahun.

Penentuan subjek dilakukan berdasarkan hasil wawancara yang telah dilakukan sebelumnya, diketahui dari 12 anak usia 5-6 tahun di sekitar Jl. Laksana Karang Tengah RT 002 terdapat 3 anak yang memiliki kriteria sikap prososial yang baik, terlebih dari aspek menolong dan berbagi sangat menonjol. Dari hasil observasi anak menunjukan sikap menolong berbagi tidak hanya di lingkungan keluarga saja, tetapi di lingkungan bermain anak tetap konsisten dengan sikap yang biasa ia lakukan di rumah, sehingga peran orang tua bisa dibilang sudah sangat baik dalam mengontrol anak di dalam maupun di luar rumah.

Teknik pengumpulan data yang digunakan dalam penelitian ini dilakukan dengan observasi dan wawancara terstruktur dengan sebelumnya peneliti menyiapkan daftar pertanyaan. Subjek primer dalam penelitian sebanyak 6 orang tua (3 bapak dan $3 \mathrm{ibu}$ ) yang ada di lingkungan tersebut. Penelitian ini menggunakan wawancara terstruktur karena tujuan dari wawancara ini lebih menemukan korelasi antara peran orang tua (bapak dan ibu) terhadap penanaman perilaku prososial kepada anak dan agar peneliti bisa mengurangi variasi jawaban yang ada sehingga didapatkan jawaban yang mengarah kepada kesimpulan bahwa hal-hal yang dilakukan orang tua berpengaruh kepada prososial anak. Analisis data menggunakan model Milles and Hubberman dengan 4 tahapan.

Penelitian ini hanya mengambil dua aspek perilaku prososial yaitu berbagi dan menolong karena keterbatasan waktu, tenaga dan biaya yang dimiliki peneliti. Adapun indikator perilaku berbagi dan menolong ditampilkan dalam bentuk tabel berikut

Tabel 1. Aspek dan indikator berbagi

\begin{tabular}{|c|l|}
\hline Aspek & \multicolumn{1}{|c|}{ Indikator } \\
\hline Berbagi & $\begin{array}{l}\text { Kesediaan untuk menolong orang } \\
\text { lain secara sukarela tanpa } \\
\text { mengharapkan imbalan. }\end{array}$ \\
& $\begin{array}{l}\text { Kesediaan untuk menolong orang } \\
\text { lain yang sedang berada dalam } \\
\text { kesulitan. }\end{array}$ \\
\hline
\end{tabular}

\begin{tabular}{|l|l|}
\hline \multirow{1}{*}{ Menolong } & $\begin{array}{l}\text { kesediaan untuk menyelamatkan } \\
\text { atau membantu orang lain yang } \\
\text { membutuhkan. } \\
\text { Menunjukan kepekaan terhadap } \\
\text { orang-orang sekitar yang } \\
\text { memerlukan pertolongan } \\
\text { (pertolongan darurat). }\end{array}$ \\
\hline $\begin{array}{l}\text { kesediaan untuk bersikap } \\
\text { dermawan pada orang lain. } \\
\text { kesediaan untuk berkorban demi } \\
\text { orang lain yang membutuhkan. } \\
\text { kesediaan untuk berbagi hal yang } \\
\text { dimiliki. }\end{array}$ \\
\hline
\end{tabular}

\section{HASIL DAN PEMBAHASAN}

Orang tua harus memiliki setidaknya 4 fungsi dalam menjalankan perannya sebagai pendidik yaitu; 1 . Orang tua sebagai pendidik; 2. Orang tua sebagai pembimbing; 3. Orang tua sebagai motivator; dan 4. Orang tua sebagai fasilitator. Berdasarkan wawancara yang dilakukan terhadap 3 subjek penelitian ditemukan temuan khusus sebagai berikut.

\section{Peran Orang Tua dalam Mengembangkan Perilaku Berbagi}

\section{Subjek Penelitian 1}

Orang tua Subjek Peneliti 1 dalam mengembangkan perilaku berbagi mencontohkan kepada anak agar senantiasa membagi rezeki yang dimiki dengan orang lain. Salah satu hal yang dilakukan yaitu dengan cara membiasakan kepada anak menyisihkan uang yang anak miliki untuk dimasukan ke kaleng infak yang tersedia di rumah untuk diberikan kepada anak yatim. Saat bermain dengan teman, orang tua juga senantiasa memberikan pesan dan memantau anak agar berbagi kepada teman temannya. Orang tua subjek penelitian 1 juga mengajarkan anak agar memiliki perilaku berbagi dengan cara menceritakan kisah nabi Muhammad S.A.W

Selain itu orang tua subjek penelitian 1 juga menyediakan fasilitas elektronik berupa telepon genggam dan laptop yang digunakan untuk menonton kisah nabi Muhammad S.A.W dan film animasi serial anak Nussa dan Rara dengan harapan 
agar anak bisa mencontoh sikap berbagi atau menjadikan teladan tokoh yang ada dalam film yang di tonton.

\section{Subjek Penelitian 2}

Orang tua subjek penelitian 2 dalam mengembangkan perilaku berbagi dengan cara memberitahu kepada anak tentang konsep berbagi, yaitu bila anak mau membagi apa yang dimiliki maka tidak akan menghabiskannya melainkan akan bertambah dan memberikan pemahaman kepada anak tentang kebaikan yang akan timbul bila anak mau berbagi, salah satunya memiliki teman yang banyak. Dalam peraktiknya orang tua subjek penelitian 2 membiasakan anak untuk memberikan uang atau minuman kemasan kepada ondel-ondel atau pengemis yang lewat di depan rumah dan juga menasehati anak untuk agar membagi makanan atau jajan yang anak miliki kepada teman atau saudaranya. Orang tua subjek penelitian 2 juga memberikan fasilitas elektronik berupa telepon genggam dan televisi

\section{Subjek Penelitian 3}

Orang tua subjek penelitian 3 mengembangkan perilaku berbagi dengan cara mengajarkan anak untuk berbagi makanan kepada teman-temannya saat anak sedang bermain. Selain itu sesekali membuat kue atau masakan yang akan diberikan kepada tetangga yang merupakan anak yatim. Orang tua subjek penelitian 3 menyediakan media elektronik berupa telepon genggam dan dvd yang digunakan untuk menonton film animasi Boneka Barbie, terkadang saat menggunakan telepon genggam anak juga suka menonton film animasi Nussa dan Rar. Dikarenakan anak sangat menyukai salah satu tokoh dalam filimasi Boneka Barbie bernama Prices Sofia, orang tua sering menjadikan tokoh Princes Sofia sebagai motivasi agar anak mau berbagi dan memiliki pribadi yang baik. orang tua subjek penelitian 3 juga mendampingi anak saat menggunakan media elektronik untuk memberikan pemahaman atau pesan yang terkandung dalam film yang anak sedang tonton.

\section{Peran Orang Tua dalam Mengembangkan Perilaku Menolong}

\section{Subjek Penelitian 1}

Orang tua Subjek Peneliti 1 mengembangkan perilaku menolong dengan mengajarkan kepada anak tentang kepedulian sosial dan meminta tolong kepada anak untuk melakukan perkerjaan orang tua di rumah, contohnya meminta mengambilkan kaos kaki sebelum ayah pergi kantor atau membantu orang tua untuk melakukan sesuatu seperti mengambilkan atau membuatkan minuman setelah makan.

Orang tua subjek penelitian 1 juga selalu menasehati anak agar mau membantu siapa saja yang sedang kesulitan contohnya saat berman, bila seorang teman ada yang terjatuh dari sepeda, langsung diberikan pertolongan atau saat sekolah bila seroang teman tidak membwa pensil warna saat pelajaran mewarnai, pinjamkan pensil warna yang anak bawa, dan contoh lainnya. Selain itu orang tua subjek penelitian 1 juga menggunakan metode menceritakan kisah nabi dan para sahabatnya untuk mengembangkan perilaku menolong ada juga penggunaan media elektronik untuk menonton kisah Nabi Muhammad S.A.W dan film animasi Nussa dan Rara.

\section{Subjek Penelitian 2}

Orang tua subjek penelitian 2 memberitahu anak untuk membantu orang tua atau orang disekitarnya yang memerlukan pertolongkan dan mengikutsertakan anak dalam melakukan pekerjaan ibu di rumah seperti menyapu, mencuci, menjemur dan sebagainya terkadang anak diminta tolong untuk membelikan keperluan dapur ke warung. Selain itu orang tua subjek penelitian 2 juga mengembangkan pemahaman tentang pentingnya perilaku menolong, karena suatu saat kita juga akan membutuhkan pertolongan. Ada juga metode bercerita yaitu menceritakan kisah binatang yang di dalamnya ada hikmah dan contoh baiknya memiliki sikap tolong menolong.

\section{Subjek Penelitian 3}

Orang tua subjek penelitian 3 mengembangkan perilaku menolong dengan cara mengajarkan agar anak mau membantu apa saja yang anak bisa lakukan dimanapun anak berada dan menjadikan tokoh yang anak suka (Princes Sophia) sebagai motivasi agar anak sentaiasa mau menolong.

Orang tua subjek penelitian 3 juga memanfaatkan kejadian yang ada di sekitar anak untuk digunakan sebagai bahan ajar anak dalam mengembangkan perilaku menolong, contoh saat di rumah anak diminta untuk membantu neneknya yang sedang menjahit atau meminta anak untuk menyiapkan keperluan ayah sebelum berangkat kerja. Adapun saat di sekolah seorang teman anak tidak membawa alat tulis orang tua subjek penelitian 3 
memerintahkan anak untuk meminjamkan alat tulis kepada temannya. Selain itu ada juga metode menonton film dan bercerita tentang Boneka Barbie yang digunakan orang tua subjek penelitian 3 untuk mengembangkan perilaku menolong.

\section{Hambatan orang tua dalam mengembangkan perilaku berbagi dan menolong pada anak}

\section{Subjek Penelitian 1}

a. Pendidik dan Motivator

Masalah terkait emosi anak. Ketika emosi anak kurang baik berdampak kepada perilaku anak juga. pendekatan dilakukan orang tua dengan berbicara dari hati ke hati kepada anak agar anak mendapatkan pengertian penyebab emosi anak, lalu dicoba mencari solusinya.

b. Pembimbing / mentor

Perbedaan pengajaran dan perilaku yang anak dapat di lingkungan bermain dari teman dan di rumah dari orang tua tentang sikap berbagi dan menolong. ada juga kendala keterbatasan waktu yang dimiliki ayah saat di rumah menyebabkan tidak maksimalnya peran orang tua sebagai pembimbing. Oleh karena itu orang tua subjek penelitain 2 menerapkan sikap prososial berbagi dan menolong kepada teman sepermainnya juga. Adapun untuk ayah selalu mencoba untuk memaksimalkan waktu yang ada di rumah untuk menjalankan peran sebagai mentor atau pembimbing.

c. Fasilitator

Kendala memberikan pesan yang terkandung dalam film kepada anak. Terkadang anak tidak paham atau tidak mengerti pesan apa yang coba diberikan kepada anak maka orang tua subjek penelitian 1 tidak memberikan pesan saat menonton melainkan mencari waktu luang dan contoh yang lebih dimengerti oleh anak.

\section{Subjek Penelitian 2}

a. Pendidik: Emosi anak yang terkadang fluktuatif, maka orang tua subjek penelitian 1 mengajak anak untuk bepergian dalam rangka menghilangkan emosi anak.

b. Fasilitator: Anak jadi kecanduan bermain gawai. Orang tua subjek penelitian 2 mengajak anak untuk melakukan hal lain yang sekiranya bisa membuat anak berhenti menggunakan gawai. salah satunya dengan berjalan jalan atau mengunjungi kerabat dekat.

\section{Subjek Penelitian 3}

a. Pendidik

Ketika orang tua sedang mencontohkan perilaku berbagi dan menolong anak tidak memperhatikan atau tidak mengerti bahwa apa yang dilakukan orang tua itu dalam rangka memberikan contoh, maka orang tua subjek penelitian 3 mengikut sertakan anak dalam kegiatannya.

b. Pembimbing

Jadwal kegiatan yang telah dibuat untuk anak tidak berjalan dengan semestinya, baik karena anak yang kurang tertarik dengan jadwal kegiatan maupun orang tua yang lupa dan kurang termotivasi. Untuk melakukan jadwal kegiatan yang telah dibuat oleh karena itu orang tua subjek penelitian 3 harus lebih fokus dan komitmen kepada jadwal kegiatan yang telah dibuat serta mencoba mencari kegiatan yang sekiranya anak lebih antusias dalam melakukannya

c. Fasilitator

Lemahnya finansial keluarga. Hal ini menyebabkan orang tua tidak bisa memenuhi kemauan anak maka anak dibiasakan untuk menabung dalam rangka membantu orang tua membelikan apa yang anak mau.

d. Motivator

Perbedaan reward yang dijanjikan kepada anak oleh orang lain selain orang tua tetapi dibebankan kepada orang tua. Saat orang tua tidak bisa memenuhnya menyebabkan anak menjadi tidak baik emosinya, maka orang tua subjek penelitain 3 membujuk secara perlahan dan mencoba memenuhi keinginan anak dengan hal lain.

Peran orang tua sebagai pendidik dalam mengembangkan perilaku berbagi. Orang tua subjek penelitian 1, 2 dan 3 telah melakukan peran orang tua sebagai pendidik yaitu dengan cara: 1 . mencontohkan, mengajarkan dan menasehati anak untuk berbagi baik dalam bentuk makanan maupun uang serta memberikan pemahanan kepada anak tentang pentingnya untuk berbagi keapada orang lain Peran orang tua sebagai pembimbing dalam mengembangkan perilaku berbagi.

Peran orang tua sebagai motivator dalam mengembangkan perilaku berbagi. Hanya orang tua subjek penelitian 3 yang melakukan peran orang tua sebagai motivator yaitu menjadikan seorang 
karakter film yang anak sukai (Sophia) sebagai teladan bagi kehidpannya. disaat anak tidak mau berbagi karena alasan tertentu maka orang tua akan mengatakan bahwa hal yang demikian itu tidak seperti sikap pada karakter Shopia. setelah itu anak termotivasi untuk berbagi Kembali.

Peran Orang Tua dalam Mengembangkan Perilaku Menolong. Orang tua subjek penelitian 1, 2 dan 3 mengembangkan perilaku menolong dengan cara mengajarkan dan menasehati anak tentang pentingnya kepekaan sosial yaitu ringan tangan dalam membantu pekerjaan orang lain di sekitarnya. anak juga diajak untuk melakukan pekerjaan orang tua di rumah terlebih pekerjaan ibu seperti memasak, mencuci piring, menyapu dan mengepel, membuang sampah dan memberli keperluan dapur ke warung yang berada di sekitar rumah.

Peran orang tua sebagai motivator dalam mengembangkan perilaku menolong. Orang tua subjek penelitian 3 memotivasi anaknya menggunakan karakter kartun yang anak sukai. sama seperti saat anak tidak mau berbagi, saat anak tidak mau menolong orang tua memberikan motivasi kepada anak dengan mengatakan bahwa hal yang ia lakukan itu tidak seusuai dengan sikap karakter yang anak suka, setelah itu anak Kembali termotivasi untuk menlong orang yang ada di sekitar.

Peran orang tua sebagai fasilitator dalam mengembangkan perilaku menolong. Orang tua subjek penelitian 1, 2 dan 3 menyediakan buku cerita tentang kisah kisah teladan agar anak memiliki perilaku menolong mulai dari kisah Nabi Muhammad, para sahabat nabi, kisah kisah binatang seperti si kancil, serial anak nussa rara dan film barbie. saat menonton dengan anak orang tua menjelaskan isi atau kandungan yang ada dalam tontonan kepada anak, terkadang orang tua memilihkan tema tersendiri yang berkaitan dengan sikap tolong menolong. maka dari itu peran orang tua sebagai fasilitator tidak hanya mempersiapkan media penunjang tetapi orang juga menyisihkan waktu untuk bersama anak

Peran orang tua sebagai motivator dalam mengembangkan perilaku menolong. Orang tua subjek penelitian 1, 2 dan 3 tidak melakukan hal kusus untuk memotivasi anak agar memiliki perilaku menolong. orang tua hanya melakukan hal hal yang bersifat antisipasi untuk menangkan anak seperti yang akan di bahas pada kendala dan solusi.
Kendala yang didapatkan oleh orang tua subjek penelitian 1, 2 dan 3 sebagai pendidik dalam mengembangkan perilaku berbagi dan menolong adalah emosi anak yang kurang baik atau mood anak yang mudah berubah menyebabkan anak tidak mau mendengarkan, mengikuti atau memperhatikan apa yang sedang dicontohkan, diajarkan oleh orang tua. oleh karena itu menurut mereka solusi yang bisa digunakan yaitu dengan mencari tau apa penyebab anak emosi atau penyebab mood anak menjadi tidak bagus lalu dicari solusinya bisa juga dengan mengajak anak berjalan jalan sekedar untuk menghilangkan emosi anak. Sesuai dengan yang dikatakan oleh Sarwono dan Meinarno (2009) ketika suasana hati anak sedang gembira akan lebih mudah untuk melakukan kebaikan. Sedangkan dalam suasana hati yang sedih atau kurang baik, anak akan kurang agak enggan dalam melakukannya, karena suasana hati dapat mempengaruhi seorang anak untuk bersikap baik. maka perlu diakukan upaya upaya diatas agar anak bisa menerima hal hal yang dimaksud orang tua.

Terkait dengan kendala dalam melaksanakan peran orang tua sebagai pembimbing dalam mengembangkan perilaku berbagi dan menolong. Kendala yang dihadapi orang tua subjek penelitian 1 adalah berbedanya pengajaran antara lingkungan bermain dan apa yang diajarkan di rumah. ini menyebabkan anak jadi ragu untuk melakukan berbagi dan menolong yang biasa dilakukan di rumah. oleh karena itu orang tua subjek penelitian 1 selain mengajarkan kepada anaknya juga mengajarkan kepada teman teman sepermainnya, agar diharpkan terjadi kesamaan dalam mengembangkan perilaku di lingkungan rumah dan lingkungan bermain. Matondang (2016) mengatakan salah satu faktor yang memperngaruhi perilaku prososial adalah kekonsistenan yang menjadi kebiasaann. oleh karena itu pentingnya menyelaraskan antara lingkungan bermain dan pengajaran di rumah. lain halnya dengan orang tua subjek penelitian 3 yang menjadi kendala adalah kurangnya komitmen orang tua dalam menjalankan jadwal yang telah dibuat untuk anak.

Oleh karena itu orang tua lebih membuat jadwal kegiatan untuk anak yang disesuaikan dengan kegiatan orang tua di rumah. Jadi anak lebih dilibatkan dalam kegiatan orang tua. Sarwono \& Meinarno (2009) mengatakan perlunya sebuah model dalam mengembangkan perilaku prososial, jadi bila anak ingin mengikuti jadwal kegiatan yang telah dibuat oleh orang tua maka orang tua lah yang 
harus paling berkomitmen untuk menjalankan kegiatan tersebut.

Adapun kendala pelaksanaan peran orang tua sebagai motivator dalam mengembangkan perilaku berbagi dan menolong. Orang tua subjek penelitian 3 memiliki kendala dalam memberikan apresiasi atau hadiah kepada anak bila itu dijanjikan oleh pihak ke 3 karena sering kali apa yang dijanjikan oleh pihak ke 3 tidak sesuai dengan kemampuan orang tua untuk memenuhinya. dalam menghadapi hal tersebut orang tua subjek penelitian 3 mencoba untuk mengalihkan kepada hal lain yang disukai oleh anak. Nur (2015) mengatakan Motivasi merupakan daya penggerak atau pendorong untuk melakukan sesuatu. Orang tua berperan menumbuhkan motivasi pada anak dalam berperilaku. jadi saat ada hal yang tidak bisa didapatkan oleh orang tua cobalah mengganti dengan hal lain yang disukai anak agar anak tetap termotivasi dan tidak kecewa.

Kendala pelaksanaan peran orang tua sebagai fasilitator dalam mengembangkan perilaku berbagi dan menolong. Kendala yang didapat orang tua subjek penelitian 1, 2 dan 3 sebagai fasilitator adalah kesulitan dalam menerjemahkan pesan pesan yang ada dalam film agar mudah di terima oleh anak. terkadang anak juga terlalu fokus kepada film jadi tidak mendengarkan atau memperhatikan penjelasan yang orang tua berikan. solusi yang diberikan orang tua subjek penelitian 1 adalah dengan memberikan penjelasan tentang film di waktu lain tidak saat anak menonton film. Kendala lain saat orang tua memberikan fasilitas alat elektronik adalah anak jadi tidak mau mengerjakan hal lain. Maka dari itu perlunya pembatasan atau pemberian kegiatan lain dengan anak orang tua subjek penelitain 2 menyarankan untuk mengajak anak jalan jalan ke luar atau sekedar menemui kerabat terdekat. Terkadang dalam memenuhi fasilitas untuk mendukung penanaman perilaku prososial pada anak orang tua subjek penelitian 3 mengalami kesulitan dalam keuangan rumah tangga, oleh karena itu anak juga dilibatkan untuk menabung untuk mendapatkannya.

\section{SIMPULAN DAN SARAN}

Berdasarkan hasil penelitian, maka simpulan yang dapat disampaikan adalah bahwa: 1). orang tua sudah melaksanakan perannya sebagai pendidik dengan cara mencontohkan, mengajarkan menasehati anak agar memiliki perilaku berbagi, menggunakan metode bercerita dan bermain peran. Adapun untuk perilaku menolong orang tua melibatkan anak untuk melakukan pekerjaan di rumah; 2). Orang tua sudah melakukan perannya sebagai pembimbing tetapi belum maksimal, karena tidak adanya kegiatan atau upaya orang tua yang menjadi acuan agar anak bisa berperilaku berbagi; 3). Orang tua sudah melakukan perannya sebagai motivator kepada anak tetapi seringkali tujuannya hanya untuk menghilangkan sikap anak yang sedang marah atau emosinya tidak baik. Sehingga kurangnya tercipta reward and punishment yang seimbang; dan 4). Orang tua sudah melaksanakan perannya sebagai fasilitator yaitu dengan menyisihkan uang dan makanan untuk diberikan kepada orang lain, serta media elektronik untuk digunakan menonton film yang menjadi teladan untuk anak berperilaku berbagi. Namun peran orangtua sebagai pembimbing dan motivator belum terlaksana dengan baik.

Adapun kendala yang dialami orangtua adalah: 1). emosi dan mood anak yang mudah berubah; 2). konsistensi dalam pelaksanaan pengajaran antara lingkungan rumah dan lingkunga bermain serta konsistensi dalam menjalankan program atau kegiatan yang sudah dibuat untuk anak; 3). Terkait motivasi, seringkali apa yang dibutuhkan dan diinginkan oleh anak tidak dapat dipenuhi orang karena faktor keuangan rumah tangga.

Terdapat beberapa saran terhadap peran orang tua dalam mengembangkan perilaku berbagi dan menolong pada anak antara lain: bagi orang tua harus lebih mampu memerankan dirinya secara multi fungsi, yakni: sebagai pendidik, sebagai pembimbing, sebagai motivator dan sebagai fasilitator. Orang tua acapkali dihadapkan kepada berbagai kendala orang tua dalam menjalankan peran sebagai pendidik. Namun, semua kendala tersebut harus diubah menjadi suatu tantangan yang harus dicarikan jawaban dan solusinya secara efektif.

Orang tua perlu melakukan komunikasi dan konsultasi jika dihadapkan kepada kendala yang sulit dipecahkannya. Tentu konsultasi dan komunikasi tersebut harus dilakukan kepada ahlinya, seperti guru, psikolog, ulama, ustadz, dan orang-orang yang memiliki keilmuan mengenai hal tersebut. 


\section{DAFTAR PUSTAKA}

Ahmid, A \& Uhbiyati. N (2015). Ilmu Pendidikan. Jakarta: Rineka Cipta.

Anisa, N., Rahmawati, A., \& Matsuri. (2014). Faktor-Faktor yang Mempengaruhi Perilaku Antisosial Anak Usia 4-5 Tahun di TK Eka Puri Mandiri Manahan Banjarsari Surakarta Tahun Ajaran 2013/2014. Jurnal Pendidikan.

Baron, R.A. dan Byrne, D. (2005). Psikologi Sosial. Edisi kesepuluh: jilid 2. Jakarta: Erlangga

Bashori, K.. (2017). Menyemai Perilaku Prososial di Sekolah. Sukma: Jurnal Pendidikan.

Beaty, J. J. (2013). Observasi Perkembangan Anak Usia Dini Edisi Ketujuh. Jakarta: Kencana.

Carlo, G \& Randall, B. (2002). The Development of a Measure of Prosocial Behaviors for Late Adolescencst. Journal of Youth and Adolescence. Jurnal Pendidikan.

Dacholfany, M. I. \& Hasanah, U. (2018). Pendidikan Anak Usia Dini Menurut Konsep Islam. Jakarta: Amzah.

Elvrida Sandra Matondang (2016). Analisis Perilaku Prososial (Prosocial Behavior) Anak Usia Dini pada Pengelompokan Usia Rangkap (Multiage Grouping). Skripsi.
Hafidhuddin, D. (2004). Panduan Praktis Tentang Zakat, Infak dan Sedekah, Cet; IV. Jakarta: Gema Insani Press.

Lay, J. C., \& Hoppmann, C. A. (2015). Altruism and prosocial behavior. Encyclopedia of geropsychology

Mulyasa, H. E. (2012). Manajemen PAUD. Bandung: PT. Remaja Rosdakarya.

Muryadi \& Matulessy, A. (2012). Religiusitas, Kecerdasan Emosi dan Perilaku Prososial Guru. Jakarta: Jurnal Psikologi.

Permendikbud Nomor 146 Tahun 2014 Tentang Kurikulum 2013 PAUD.

Purba, D.E. (2008). Pengaruh Tayangan Berita Kriminal Terhadap Kecenderungan Perilaku Menolong. Skripsi.

Sarwono, S W. \& Eko A. M. (2009). Psikologi Sosial. Jakarta: Penerbit Salemba Humanika.

Undang-undang Nomor 20 Tahun 2003 Tentang Sistem Pendidikan Nasional.

Wentzel, K. (2015). Prosocial Behavior and Schooling. Encyclopedia on Early Childhood Development. USA: University of Maryland at College Park. Jurnal Pendidikan.

Widyastuti, Y. (2014). Psikologi Sosial. Yogyakarta: Graha Ilmu. 